\author{
Marquette University \\ e-Publications@Marquette
}

$1-30-2002$

\title{
Electrochemistry and Spectroscopy of Sulfate and Thiosulfate Complexes of Iron Porphyrins
}

Philip Walter Crawford

Marquette University

Michael D. Ryan

Marquette University, michael.ryan@marquette.edu

Follow this and additional works at: https://epublications.marquette.edu/chem_fac

Part of the Chemistry Commons

\section{Recommended Citation}

Crawford, Philip Walter and Ryan, Michael D., "Electrochemistry and Spectroscopy of Sulfate and Thiosulfate Complexes of Iron Porphyrins" (2002). Chemistry Faculty Research and Publications. 151. https://epublications.marquette.edu/chem_fac/151 


\title{
Electrochemistry and Spectroscopy of Sulfate and Thiosulfate Complexes of Iron Porphyrins
}

\author{
Phillip W. Crawford \\ Department of Chemistry, Marquette University \\ Milwaukee, WI \\ Michael D. Ryan \\ Department of Chemistry, Marquette University \\ Milwaukee, WI
}

\begin{abstract}
The electrochemical and spectroscopic properties of the complex formed by the addition of thiosulfate to ferric porphyrins were examined. The NMR spectrum of the thiosulfate-ferric porphyrin complex was consistent with a high-spin ferric complex, while the EPR spectrum at liquid nitrogen temperatures indicated that the complex under these conditions was low-spin. Such behavior has been previously observed for other ferric-porphyrin complexes. The visible spectra were characterized by a shift in the Soret band to higher energies, with smaller changes in the longer wavelength region. The complex was reasonably stable in DMF, but slowly reduced over several hours to $\mathrm{Fe}^{\mathrm{II}}(\mathrm{TPP})$ and $\mathrm{S}_{4} \mathrm{O}_{6}{ }^{2-}$. The voltammetric behavior of the thiosulfate complex in DMF consists of two waves, the first of which was irreversible. The
\end{abstract}


ferric/ferrous reduction in the presence of thiosulfate was shifted negatively about $400 \mathrm{mV}$, compared to the $\mathrm{Fe}(\mathrm{TPP})(\mathrm{Cl})$ reduction.

The visible, NMR and EPR spectra were most consistent with a Fe-S bonded ferric porphyrin-thiosulfate complex, $\mathrm{Fe}(\mathrm{P})\left(\mathrm{S}-\mathrm{SO}_{3}\right)^{-}$. The kinetics of the reduction of ferric porphyrin by thiosulfate in DMSO indicated an autocatalytic mechanism, where the first step is the formation of the catalyst. The identity of the catalyst could not be determined because it must be present at low concentrations, but it is formed from the reaction of the ferric complex with thiosulfate. Coordination of thiosulfate to the porphyrin was not necessary for the reduction to occur, and the reduction of $\mathrm{Fe}(\mathrm{TPP})(\mathrm{Cl})$ by thiosulfate was accelerated by the addition of sulfate. Under these conditions, sulfate had replaced thiosulfate as the axial ligand for the ferric porphyrin. In the presence of sulfate, the reduction occurred in a single kinetic pseudo-first order step.

\section{Introduction}

Enzymes that metabolize small molecular compounds of nitrogen and sulfur play an important role in the biosynthesis of amino acids by plants or as a bacterial source of energy. In particular, interest has grown substantially in microbial sulfur metabolism, as exemplified by the book edited by Peck and LeGall [1]. Many of the enzymes that are in this system are not yet well characterized, but several are known to contain heme prosthetic groups (e.g., thiosulfate dehydrogenase from $T$. acidiphilus [2], sulfite reductase, and sulfite dehydrogenase [3]). The importance of these transformations in nature has lead us to investigate the reactions and electrochemistry of iron porphyrins in the presence of thiosulfate and sulfate. These ligands fit in with our general interest in the electrochemistry of complexes with electroactive ligands. Previously we have reported on the electrochemistry of iron porphyrins with nitrite [4], hydroxylamine $[5]$, and nitric oxide $[6,7]$.

Ligands which are easily oxidized are known to readily reduce ferric porphyrins, probably after complexation. For example, piperidine [8-10], cyanide $[9,11,12]$, alkyl thiols $[9,13,14]$, amines [15], tetrathiomolybdate (tungstate) [16], and hydroxide have all been shown to induce the reduction of iron(III). In general, with the exception of hydroxide, the reduction appears to involve coordination of the ligand species (L) to the Fe(III) center followed by 
intramolecular one-electron transfer, via homolytic cleavage of the Fe(III)-L bond $[10,12]$. Radical species have been detected in some cases $[9-11]$.

Recently, interest has developed in this laboratory and others in the interactions between iron porphyrins and sulfur-oxy anions in nonaqueous solvents. The first report from this laboratory has been published [17]. Dianions such as sulfate were found to form dimeric ferric porphyrin complexes in non-coordinating solvents such as methylene chloride [17-20]. Three reduction waves were observed in cyclic voltammetry due to the reduction of the dimer, the sulfate complex, and the ferrous porphyrin.

$$
\begin{array}{r}
{\left[\mathrm{Fe}^{\mathrm{III}}(\mathrm{P})\right]_{2}\left(\mathrm{SO}_{4}\right)+\mathrm{e}^{-} \rightleftharpoons \mathrm{Fe}^{\mathrm{III}}(\mathrm{P})\left(\mathrm{SO}_{4}\right)^{-}+\mathrm{Fe}^{\mathrm{II}}(\mathrm{P})} \\
\mathrm{Fe}^{\mathrm{III}}(\mathrm{P})\left(\mathrm{SO}_{4}\right)^{-}+\mathrm{e}^{-} \rightleftharpoons \mathrm{Fe}^{\mathrm{II}}(\mathrm{P})+\mathrm{SO}_{4}{ }^{2-} \text { Wave Ia } \\
\mathrm{Fe}^{\mathrm{II}}(\mathrm{P})+\mathrm{e}^{-} \rightleftharpoons \mathrm{Fe}^{\mathrm{I}}(\mathrm{P})^{-} \quad \text { Wave Ib }
\end{array}
$$

In DMSO, the visible spectroscopy and cyclic voltammetry indicated that the dimer was dissociated, and, as a result, Wave Ib was significantly attenuated [17]. Addition of sulfate to a solution of the dimer or $\mathrm{Fe}(\mathrm{P})(\mathrm{Cl})$ gave rise to two waves: Wave Ib and Wave II.

This work was continued with an investigation of the reaction with iron porphyrins and thiosulfate in nonaqueous solvents. Thiosulfate is known to be a reducing agent for Fe(III) complexes [2124]. Chen et al. [25-27] have recently investigated the oxidation of thiosulfate in an aqueous solution by water soluble iron and cobalt porphyrins, as well as the photocatalytic reaction. The work in this report involves the electrochemistry, spectroscopy, and spectroelectrochemistry of thiosulfate with iron porphyrins. In order to clarify some of the questions raised by the thiosulfate results, the chemistry and electrochemistry of the ferric sulfate complexes in DMSO and DMF were re-examined. 


\section{Experimental}

\section{Materials}

Tetraphenylporphyrin ( $\left.\mathrm{H}_{2} \mathrm{TPP}\right)$, octaethylporphyrin iron(III) chloride $(\mathrm{Fe}(\mathrm{OEP})(\mathrm{Cl}))$, tetraphenylphosphonium chloride, dimethylformamide (DMF), dimethyl sulfoxide (DMSO), DMF- $d_{7}$, DMSO- $d_{6}$, toluene, toluene- $d_{8}$, and sodium tetrathionate dehydrate were purchased from Aldrich Chemical Co. in the highest purity available. All solvents were used without further purification. The supporting electrolyte, tetrabutylammonium perchlorate (TBAP), was obtained from G. F. Smith Chemical Co., and was used as received. Sodium thiosulfate was obtained from Fisher Scientific Co. Tetraphenylporphyrinato iron(III) chloride (Fe(TPP) $(\mathrm{Cl})$ ) [28] and $[\mathrm{Fe}(\mathrm{TPP})]_{2}\left(\mathrm{SO}_{4}\right)[18]$ were synthesized by literature procedures.

Bis(tetraphenylphosphonium) thiosulfate [29] and bis(tetraphenylphosphonium) tetrathionate were prepared via the metathesis reaction between the sodium salt of the anion and tetraphenylphosphonium chloride $\left(\mathrm{Ph}_{4} \mathrm{PCl}\right)$. The difference infrared spectrum between $\mathrm{Ph}_{4} \mathrm{PCl}$ and $\left(\mathrm{Ph}_{4} \mathrm{P}\right)_{2} \mathrm{~S}_{2} \mathrm{O}_{3}$ gave bands at 548, 670, 1006 and $1134 \mathrm{~cm}^{-1}$, matching those observed for sodium thiosulfate and those calculated for the thiosulfate ion $[15,30]$. The infrared spectrum for $\left(\mathrm{Ph}_{4} \mathrm{P}\right)_{2} \mathrm{~S}_{4} \mathrm{O}_{6}$ exhibited bands which were similar to those observed for sodium tetrathionate [31] (592, 629, 1014, $1230 \mathrm{br}$, and $1245 \mathrm{~cm}^{-1}$ ). Bis(triphenylphosphoranylidene) ammonium sulfate, $(\mathrm{PNP})_{2}\left(\mathrm{SO}_{4}\right)$, was prepared from a literature procedure [32]. Chemical reduction of ferric porphyrins were carried out using the zinc amalgam method $[33,34]$.

\section{Methods}

Electrochemical data were obtained with either an ECO 553 potentiostat with an EG\&G Princeton Applied Research (PARC) 175 waveform generator or an IBM EC/225 voltammetric analyzer. Voltammetric data were recorded on a Hewlett-Packard $7045 \mathrm{X}-\mathrm{Y}$ recorder. Scan rates ranged from 5 to $200 \mathrm{mV} / \mathrm{s}$. A three-electrode IBM cell was used for the cyclic voltammetric experiments, consisting 
of Sargent-Welch platinum flag electrodes as the working and auxiliary electrodes, and a $\mathrm{Ag} / \mathrm{AgNO}_{3}(0.1 \mathrm{M}$ in acetonitrile) reference electrode (SRE). The SRE was used as the reference electrode in all electrochemical experiments. The reference electrode was separated from the porphyrin solution by either an asbestos plug or a porous Vicor tip salt bridge filled with the appropriate solvent and supporting electrolyte $(0.1 \mathrm{M})$. All solutions were deoxygenated either by bubbling the solution for $15 \mathrm{~min}$. with prepurified dinitrogen or by performing the experiments under an argon atmosphere in an HE-43-2 Dri-Lab glove box. The inert atmosphere was maintained over the solutions during all measurements. Between scans the electrodes were disconnected to prevent any back oxidation of ferrous porphyrin to ferric porphyrin. An optically transparent thin layer electrode (OTTLE) cell [35] was used for the spectroelectrochemical studies.

All visible spectra were obtained on either a Perkin-Elmer 320 UV-visible spectrophotometer with a PE 3600 data station or a Hewlett-Packard 8452A diode array spectrophotometer. Room temperature spectra were obtained with $1 \mathrm{~cm}, 1 \mathrm{~mm}$, or $2 \mathrm{~mm}$ quartz cells. A GE Omega $300 \mathrm{MHz}$ NMR spectrometer was used to obtain NMR spectra. Infrared samples were prepared as $\mathrm{KBr}$ pellets and the spectra obtained with an Analect FX-6200 FT infrared spectrometer. All mathematical operations in the kinetics section of the work were carried out using MATLAB. The PLS Toolbox 2.0 (Eigenvector Research, Inc.) algorithms for MATLAB were used for the chemometric analysis (factor analysis and multivariate curve resolution).

Product isolation studies for the reaction between $\mathrm{Fe}(\mathrm{P})(\mathrm{Cl})$, where $\mathrm{P}=\mathrm{TPP}$ or OEP, and $\left(\mathrm{Ph}_{4} \mathrm{P}\right)_{2} \mathrm{~S}_{2} \mathrm{O}_{3}$ were performed by mixing equimolar amounts of each reactant in minimal amounts of solvent, DMSO or DMF, and allowing the reactions to proceed under argon for varying lengths of time (5-17 hours). Large excesses of toluene or toluene/benzene were then added and the reaction mixtures left for varying lengths of time ( $12 \mathrm{hr}$. to 5 days) in order to precipitate any non-porphyrin products. The crystals were then washed with toluene and dried under argon. Unless noted otherwise, all solutions containing $\mathrm{Fe}(\mathrm{P})(\mathrm{Cl})$ and $\left(\mathrm{Ph}_{4} \mathrm{P}\right)_{2} \mathrm{~S}_{2} \mathrm{O}_{3}$ were prepared under an inert atmosphere.

Inorganica Chimica Acta, Vol. 328, No. 1 (2002): pg. 13-22. DOI. This article is (C) Elsevier and permission has been granted for this version to appear in e-Publications@Marquette. Elsevier does not grant permission for this article to be further copied/distributed or hosted elsewhere without the express permission from Elsevier. 


\section{Results and Discussion}

\section{Visible and NMR Spectroscopy of Ferric Porphyrin Complexes}

The visible spectra of $\mathrm{Fe}(\mathrm{P})\left(\mathrm{SO}_{4}\right)^{-}$and $[\mathrm{Fe}(\mathrm{P})]_{2}\left(\mathrm{SO}_{4}\right)$ in various solvents are shown in Table 1 . The sulfate dimer was stable in noncoordinating solvents such as methylene chloride. Some dissociation of the dimer probably occurred in DMSO, especially at low concentrations of the ferric porphyrin. In DMF, the sulfate dimer was probably present, as indicated by the shift in the Soret band to $398 \mathrm{~nm}$ [17], as compared to the Soret band for $\mathrm{Fe}(\mathrm{TPP})\left(\mathrm{NO}_{3}\right)$ in DMF which appears at 380 and $416 \mathrm{~nm}$ and for Fe(TPP)(SO 4$)-$ at $426 \mathrm{~nm}$.

The addition of $\mathrm{SO}_{4}{ }^{2-}$ to solutions of the sulfate dimer or $\mathrm{Fe}(\mathrm{TPP})(\mathrm{Cl})$ in both coordinating and non-coordinating solvents readily led to the formation of the $\mathrm{Fe}(\mathrm{TPP})\left(\mathrm{SO}_{4}\right)$-complex. The sulfate complex was characterized by a Soret band at 417-426 nm (depending upon the solvent) [17], and additional visible bands around 565 and 615 $\mathrm{nm}$. Even in DMSO, complete coordination of the ferric complex was observed with about 1-2 mM sulfate. At lower concentrations, some dissociation was observed.

The visible spectra of $\mathrm{Fe}^{\mathrm{III}}(\mathrm{P})(\mathrm{X})$, where $\mathrm{P}=$ TPP or OEP and $\mathrm{X}=$ $\mathrm{S}_{2} \mathrm{O}_{3}{ }^{2-}$ were examined. Because thiosulfate is not stable in halogenated hydrocarbons [36], the majority of the thiosulfate experiments were carried out in solvents such as DMF and DMSO. All spectroscopy studies in halogenated solvents were performed soon after mixing before any reaction with the solvent was important.

The most significant change in the visible spectrum of DMF solutions of $\mathrm{Fe}(\mathrm{TPP})(\mathrm{Cl})$ in the presence of thiosulfate occurred in the Soret region. The band at $416 \mathrm{~nm}$ shifted to a broad band at $402 \mathrm{~nm}$ in the presence of thiosulfate (Figure 1 and Table 1). Relatively smaller changes were observed in the longer wavelength region with the most significant change being the attenuation of the $650-700 \mathrm{~nm}$ bands (see Figure 1). In DMF after 30-60 min, the Soret band due to $\mathrm{Fe}^{\mathrm{II}}$ (TPP) could be observed under anaerobic conditions. The reaction was much faster when DMSO was the solvent, with all the ferric porphyrin being 
converted to ferrous porphyrin in about $5 \mathrm{~min}$. The visible spectra of the ferric-OEP complexes with thiosulfate in DMF and ethylene chloride (starting with $\mathrm{Fe}(\mathrm{OEP})\left(\mathrm{ClO}_{4}\right)$ ) are also summarized in Table 1. As with $\mathrm{Fe}(\mathrm{TPP})(\mathrm{Cl})$, the Soret bands for the ferric-OEP complex shifted to shorter wavelengths when thiosulfate was added. The spectrum of the $\mathrm{Fe}(\mathrm{OEP})$-thiosulfate complex in ethylene chloride (starting with $\left.\mathrm{Fe}(\mathrm{OEP})\left(\mathrm{ClO}_{4}\right)\right)$ in the $500-700 \mathrm{~nm}$ region was quite similar to $\mathrm{Fe}(\mathrm{OEP})(\mathrm{Cl})$ (Table 1).

The proton NMR spectra of $\mathrm{Fe}(\mathrm{TPP})(\mathrm{Cl})$ and $\mathrm{Fe}(\mathrm{OEP})(\mathrm{Cl})$ in the presence and absence of thiosulfate are summarized in Table 2. In both DMF- $d_{7}$ and DMSO- $d_{6} /$ toluene- $d_{8}\left(\right.$ at $0^{\circ} \mathrm{C}$ ), the proton NMR spectra in the presence and absence of thiosulfate are consistent with a high-spin ferric complex $[17,18]$, though small changes in the chemical shifts were observed when thiosulfate was present. For example, the pyrrole resonance of $\mathrm{Fe}(\mathrm{TPP})(\mathrm{Cl})$ in $\mathrm{DMF}-\mathrm{d}_{7}$ was shifted from $82.5 \mathrm{ppm}$ to $77.0 \mathrm{ppm}$ when thiosulfate was added. Similar shifts were observed in DMSO- $d_{6} /$ toluene- $d_{8}$ at $0^{\circ} \mathrm{C}$. In the presence of thiosulfate, the pyrrole resonance $(77.0 \mathrm{ppm})$ was between that of the sulfate dimer and $\mathrm{Fe}(\mathrm{TPP})(\mathrm{Cl})$.

While the complex was high-spin at room temperature, the EPR evidence indicates that the complex shifts to a low-spin complex in the frozen state at $77 \mathrm{~K}$. In DMF, the complex shifts completely to the lowspin complex with g-values of $2.41,2.27$ and 1.93 , which is similar to the $g$-values of other ferric porphyrins with thiolate ligands (Fe(OEP)(SPh)(DMF): 2.42, 2.27 and 1.92 [43]). The intensity of the high-spin EPR signal decreased linearly with the concentration of thiosulfate, reaching zero intensity with a $1: 1$ ferric porphyrin/thiosulfate ratio. As the high-spin signal decreased, the lowspin signal appeared, with no evidence of an EPRsilent thiosulfate bridged dimer.

The formation of the thiosulfate complex is thermodynamically favored in that only a small excess of thiosulfate is needed to form the spectrum. The most characteristic feature of the visible spectrum in DMF is the shift in the Soret band to higher energy (416 to $400 \mathrm{~nm}$ ). This is contrary to the shift observed for the $\mathrm{Fe}(\mathrm{P})\left(\mathrm{SO}_{4}\right)^{-}$complexes (416 to $426 \mathrm{~nm}$ ). On the other hand, iron-sulfur coordination has been

Inorganica Chimica Acta, Vol. 328, No. 1 (2002): pg. 13-22. DOI. This article is (C Elsevier and permission has been granted for this version to appear in e-Publications@Marquette. Elsevier does not grant permission for this article to be further copied/distributed or hosted elsewhere without the express permission from Elsevier. 
observed to shift the Soret band to higher energies, compared to halide coordination [44-46]. The shift in the Soret band to shorter wavelengths in the presence of thiosulfate was unlikely to be due to dimer formation because the dimer would not form in the presence of excess thiosulfate, and the sulfate studies showed that the dimer did not form if chloride was also present (starting with $\mathrm{Fe}(\mathrm{TPP})(\mathrm{Cl})$ ).

\section{Voltammetry of Ferric Porphyrin-Sulfate and Thiosulfate Complexes}

The cyclic voltammetry of the sulfate dimer and monomer in coordinating and non-coordinating solvents has already been examined [17]. If there is an excess of sulfate, the first wave in all solvents was the reduction of the ferric sulfate monomer to the ferrous porphyrin, while the second wave was the reduction of the ferrous porphyrin. The first wave was quite quasi -reversible with $\Delta \mathrm{E}_{\mathrm{p}}$ values of about $400 \mathrm{mV}$ (Figure 2A), even though the sulfate remains complexed with the ferrous porphyrin at high concentrations of sulfate (see spectroelectrochemical data below).

When a stoichiometric amount of thiosulfate was added to a solution of $\mathrm{Fe}(\mathrm{TPP})(\mathrm{Cl})$ in DMF, Wave Ia almost completely disappeared and a new wave (Wave Ib) occurred with an Epc value of about $-1.1 \mathrm{~V}$ (Figure 2B), which was typical of the behavior of ferric porphyrins with sulfate. The appearance of the new wave correlated with the changes in the visible and NMR spectra, as reported above. Thiosulfate readily displaced chloride in DMF, as indicated by the appearance of Wave Ib when substoichiometric amounts of thiosulfate were added (Table 3). The significant feature of the voltammetry is the irreversible electron transfer kinetics of Wave Ib, as is indicated by $\Delta \mathrm{E}_{\mathrm{p}}$ values between $700-800 \mathrm{mV}$. This wave corresponds to the reduction/oxidation of the ferric-thiosulfate complex.

$$
\mathrm{Fe}^{\mathrm{III}}(\mathrm{P})\left(\mathrm{S}_{2} \mathrm{O}_{3}\right)^{-}+\mathrm{e}^{-} \rightleftharpoons \mathrm{Fe}^{\mathrm{II}}(\mathrm{P})+\mathrm{S}_{2} \mathrm{O}_{3}{ }^{2-} \text { Wave Ib }
$$

The origin of such slow electron transfer kinetics is the loss/gain of the axial ligand (thiosulfate) during the redox process. The $E_{1 / 2}$ value for Wave Ib can be estimated based on the average of the anodic and cathodic peak potentials. From the shift in the $E_{1 / 2}$ values,

Inorganica Chimica Acta, Vol. 328, No. 1 (2002): pg. 13-22. DOI. This article is @ Elsevier and permission has been granted for this version to appear in e-Publications@Marquette. Elsevier does not grant permission for this article to be further copied/distributed or hosted elsewhere without the express permission from Elsevier. 
a formation constant (KTS, $\mathrm{Cl}$ ) for the displacement of chloride by thiosulfate from the ferric porphyrin complex is estimated to be $4 \mathrm{x}$ $10^{3}$. Unfortunately, the narrow range of thiosulfate solubility (up to 3-4 $\mathrm{mM}$ ) prevents an accurate determination of this value.

$$
\mathrm{Fe}(\mathrm{TPP})(\mathrm{Cl})+\mathrm{S}_{2} \mathrm{O}_{3}{ }^{2-} \rightleftharpoons \mathrm{Fe}(\mathrm{TPP})\left(\mathrm{S}_{2} \mathrm{O}_{3}\right)^{-}+\mathrm{Cl}-\mathrm{K}_{\mathrm{TS}, \mathrm{Cl}}
$$

Because $\mathrm{Fe}(\mathrm{TPP})(\mathrm{Cl})$ was rapidly reduced by thiosulfate in DMSO, the voltammetry was carried out using $\mathrm{Fe}^{\mathrm{II}}$ (TPP) which was obtained by the zinc amalgam reduction of $\mathrm{Fe}(\mathrm{TPP})(\mathrm{Cl})$ in toluene. The results were analogous to those observed in DMF, with the disappearance of Wave Ia when stoichiometric amounts of thiosulfate were present.

The fact that no wave was observed at Wave Ia when the concentration of thiosulfate exceeded stoichiometric amounts indicates that the thiosulfate coordination with $\mathrm{Fe}^{\mathrm{III}}(\mathrm{P})$ is stronger than sulfate coordination in DMF. The similarity between the cyclic voltammetry of $\mathrm{Fe}(\mathrm{P})\left(\mathrm{SO}_{4}\right)^{-}$in methylene chloride and the ferric-thiosulfate complex in DMF or DMSO is consistent with a $1: 1$ ferric porphyrin/thiosulfate complex, $\mathrm{Fe}(\mathrm{P})\left(\mathrm{S}_{2} \mathrm{O}_{3}\right)^{-}$.

\section{Spectroelectrochemistry of $\mathrm{Fe}(\mathrm{P})(\mathrm{Cl})$ in the Presence of Thiosulfate}

The spectroelectrochemical oxidation of $\mathrm{Fe}^{\mathrm{II}}$ (TPP) in the presence and absence of thiosulfate was examined in DMF. In the absence of thiosulfate, the oxidation of $\mathrm{Fe}^{\mathrm{II}}(\mathrm{TPP})$ in DMF yielded the spectrum for $\mathrm{Fe}^{\mathrm{III}}(\mathrm{TPP})^{+}$with bands at 416, 499, 530, 650s and 690 $\mathrm{nm}$ [47]. The original spectrum was regenerated by stepping the potential back to the original value, $-1.30 \mathrm{~V}$. Repeating the oxidation in the presence of $3.8 \mathrm{mM}$ thiosulfate resulted in a spectrum with bands at 401, 424, 514 and 570s nm (Figure 1). The original Fe ${ }^{\mathrm{II}}$ (TPP) spectrum was obtained when the potential was returned to $-1.3 \mathrm{~V}$. There was no evidence for coordination between thiosulfate and $\mathrm{Fe}^{\mathrm{II}}(\mathrm{TPP})$ in DMF. This contrasts strongly with the spectroelectrochemistry of $[\mathrm{Fe}(\mathrm{TPP})]_{2}\left(\mathrm{SO}_{4}\right)$ in the presence of $4 \mathrm{mM}$ sulfate. In this case, the Soret band for a 5-coordinate anion complex can be observed $\left(\lambda_{\max }=438 \mathrm{~nm}\right)$, along with the neutral Fe(TPP) band 
at $429 \mathrm{~nm}$ (in the absence of added sulfate, only the Soret band for $\mathrm{Fe}$ (TPP) can be observed). The longer wavelength region is also consistent with sulfate coordination, though the shifts in this region are less dramatic (564 and $606 \mathrm{~nm}$ to 569 and $609 \mathrm{~nm}$, respectively).

A similar set of experiments was carried out using DMSO as the solvent. The most significant difference was the change in the Soret region. Two Soret bands were observed at 403 and $426 \mathrm{~nm}$. The longer wavelength region was quite similar to the DMF results, though some peaks appeared as shoulders. The s me spectrum can be obtained at $0^{\circ} \mathrm{C}$, using a DMSO/DMF mixed solvent.

\section{Kinetic Study of the Reduction of $\mathrm{Fe}^{I I I}(\mathrm{P})(\mathrm{Cl})$ by Thiosulfate}

As was indicated above, ferric porphyrins are reduced by thiosulfate. The reaction rate is substantially faster in DMSO than in DMF. The reaction can be conveniently followed by visible spectroscopy. In DMSO, the Soret band for $\mathrm{Fe}^{\mathrm{II}}(\mathrm{TPP})$ was observed soon after mixing the ferric porphyrin with thiosulfate (Figure 3). The predominant feature in the absorbance-time curves was a short induction period, which occurred immediately after mixing. The length of the induction period depended upon temperature, and was substantially longer at $0^{\circ} \mathrm{C}$ (in a mixed DMF/DMSO solution). The presence of an induction period was consistent with a multi-step mechanism.

The analysis of the absorbance changes as a function of time was carried out utilizing two chemometric techniques: evolving factor analysis and multivariate curve resolution (MCR) [48]. The first approach, (window) evolving factor analysis, is a useful technique for determining the number of absorbing components present at any time during the experiment. A typical set of eigenvalues obtained using a 10-s window are shown in Figure 4. These results were consistent with the presence of only two absorbing components during the reaction time (the very small third factor at the very beginning of the experiment is an artifact; good isosbestic points are observed in that region). The same conclusion was obtained for different concentrations of ferric porphyrin and thiosulfate. Because all of these experiments 
were carried out with an excess of thiosulfate, the two spectral species were $\mathrm{Fe}^{\mathrm{III}}(\mathrm{TPP})\left(\mathrm{S}_{2} \mathrm{O}_{3}\right)^{-}$and $\mathrm{Fe}^{\mathrm{II}}(\mathrm{TPP})$ (the latter species could be clearly identified at the end of the reaction).

The spectra of the individual species were determined using multivariate curve resolution (MCR). This technique allows one to extract the concentration profiles and component spectra with as few assumptions about the data as possible. A typical set of results are shown in Figure 5. In obtaining these results, it was assumed that the concentrations and spectra of all the components were non-negative. In addition, the concentrations of $\mathrm{Fe}^{\mathrm{II}}(\mathrm{TPP})$ and $\mathrm{Fe} \mathrm{III}^{\mathrm{II}}(\mathrm{TPP})\left(\mathrm{S}_{2} \mathrm{O}_{3}\right)^{-}$at long times were equal to the initial concentrations of the ferric porphyrin and zero, respectively. The spectrum of species 2 was clearly equal to $\mathrm{Fe}^{\mathrm{II}}(\mathrm{TPP})$, and the spectrum of species 1 was consistent with the spectrum of $\mathrm{Fe}(\mathrm{TPP})\left(\mathrm{S}_{2} \mathrm{O}_{3}\right)^{-}$obtained by spectroelectrochemistry. The concentration profiles for the ferric porphyrin with different concentrations of thiosulfate are shown in Figure 6 . The predominant feature in all these deconvolutions is that the induction period could be observed for both the ferric species and the ferrous species. In addition, the loss of the ferric porphyrin was equal to the gain in the ferrous species, indicating that the final step in the reaction was the reduction of $\mathrm{Fe}$ the initial step in this mechanism does not involve the reduction of a significant amount of ferric porphyrin, though the ferric porphyrin must be present in order to initiate the reaction. Finally, while the reaction rate does increase with the concentration of thiosulfate, it becomes less dependent upon thiosulfate at high concentrations. The concentration profile for different concentrations of ferric porphyrin (maintaining the concentration of thiosulfate constant) are shown in Figure 7 . The rate of the reaction was clearly dependent upon the concentration of ferric porphyrin, decreasing substantially at high concentrations of ferric porphyrin. It is unlikely that a dimeric species is present at significant concentrations because of the use of strongly coordinating solvent (DMSO) and the presence of reasonably strong ligands such as chloride and excess thiosulfate.

Inorganica Chimica Acta, Vol. 328, No. 1 (2002): pg. 13-22. DOI. This article is (C) Elsevier and permission has been granted for this version to appear in e-Publications@Marquette. Elsevier does not grant permission for this article to be further copied/distributed or hosted elsewhere without the express permission from Elsevier. 
Attempts to fit the kinetic data to a classical two-step mechanism below were unsuccessful:

$$
\mathrm{A} \underset{k_{-1}}{\stackrel{k_{1}}{\rightleftharpoons}} \mathrm{B} \stackrel{k_{2}}{\rightarrow} \mathrm{C}
$$

While reasonable fits to the experimental data could be obtained over a limited range of concentrations, it was difficult to obtain reproducible rate constants or induction periods that were consistent with the data. A more complex mechanism would be required to explain the data.

Results similar to ours were reported by Kalinichenko et al. [49], who investigated the reduction of aqueous solutions of Fe(III) by thiosulfate. The mechanism that they proposed was the initial generation of a catalyst that would oxidize thiosulfate. This catalyst was then regenerated by the ferric ion:

$$
\begin{array}{r}
\mathrm{Fe}^{3+}+\mathrm{S}_{2} \mathrm{O}_{3}^{2-} \rightarrow \mathrm{C}+\text { products } \\
\mathrm{Fe}^{3+}+\mathrm{C}^{-} \rightarrow \mathrm{Fe}^{2+}+\mathrm{C} \\
\mathrm{S}_{2} \mathrm{O}_{3}^{2-}+\mathrm{C} \rightarrow \mathrm{S}_{2} \mathrm{O}_{3}^{-}+\mathrm{C}^{-} \\
\mathrm{S}_{2} \mathrm{O}_{3}^{-}+\mathrm{FeS}_{2} \mathrm{O}_{3}^{+} \rightarrow \mathrm{S}_{4} \mathrm{O}_{6}^{2-}+\mathrm{Fe}^{2+}
\end{array}
$$

The ferric species in Reactions 2 and 3 could also be coordinated with thiosulfate. In addition, $\mathrm{S}_{2} \mathrm{O}_{3}{ }^{-}$could react with $\mathrm{S}_{2} \mathrm{O}_{3}{ }^{2-}$ to form $\mathrm{S}_{4} \mathrm{O}_{6}{ }^{3-}$, a more potent reducing agent than $\mathrm{S}_{2} \mathrm{O}_{3}{ }^{-}$, which could be the reductant in Reaction 5 [50]. If we assume that the rate constant for Reaction 5 $\left(k_{5}\right)$ is large, the following rate law can be obtained:

$$
\frac{\mathrm{d}\left[\mathrm{Fe}^{3+}\right]}{\mathrm{d} t}=\frac{k_{3} k_{4}[\mathrm{C}]\left[\mathrm{S}_{2} \mathrm{O}_{3}^{2-}\right]\left[\mathrm{Fe}^{3+}\right]}{k_{3}\left[\mathrm{Fe}^{3+}\right]+k_{4}\left[\mathrm{~S}_{2} \mathrm{O}_{3}^{2-}\right]}
$$

where $\mathrm{k}_{3}$ and $\mathrm{k}_{4}$ are the rate constants for Reactions 3 and 4, respectively. It will be assumed that $C$ is present at steady-state after an initial rise, and it is only formed upon the mixing of thiosulfate with iron(III) (Reaction 2) with a rate constant, $\mathrm{k}_{2}$. The induction period was primarily determined by the rate at which the catalyst $C$ was generated. With this assumption, the values of $k_{2}, k_{3}$ and $k_{4}$ can be 
determined by using a range of concentrations of ferric porphyrin and thiosulfate. The best fit for all the experimental data is shown in Figures 6 and 7 using the following set of kinetic parameters: $\mathrm{k}_{3} \mathrm{k}_{4}[\mathrm{C}]$ $=0.88 \mathrm{M}^{-1} \mathrm{~s}^{-2}$ and $\mathrm{k}_{3} / \mathrm{k}_{4}=32$. Without a knowledge of the identify or concentration of the catalyst, $\mathrm{C}$, only relative values of the rate constant can be determined. The relative values, though, are useful in providing a quantitative way to evaluate the mechanism.

The mechanism described in Reactions 2-4 gives rise to a complex relationship between the rate constant(s) and the concentrations of thiosulfate and ferric porphyrin. In particular, the observed reaction rates appear to decrease as the ferric porphyrin concentration increases, and the increase in the reaction rate with thiosulfate is less than first order. This is consistent with Eq. 6 in that both the ferric concentration and thiosulfate is in the denominator of the equation. At high concentrations of either reactant, the reaction becomes zero order. This is because of the catalytic nature of the reaction mechanism, in that both reactions (Reactions 3 and 4) must be fast for the overall reaction to be fast.

The autoreduction of ferric porphyrins in DMSO has been noted for a number of anions, including hydroxide [51, 52], methoxide [53], cyanide $[11,12]$, and mercaptides [14]. While the kinetics of the autoreduction has not been examined for all of these species, kinetic analysis of the cyanide reduction of $\mathrm{Fe}(\mathrm{TPP})^{+}$indicated that the reduction was pseudo-first order in cyanide $[11,12]$. These reactions have not been observed in solvents other than DMSO [51]. The mechanism of the metal reductions by thiosulfate is often more complex than pseudo-first order reduction. Early work by Page [54] indicated that the reduction of aqueous ferric ion by thiosulfate was half-order in thiosulfate and 3/2 order in ferric ion. The reduction of aqueous cobalt(III) oxalate by thiosulfate was sluggish without trace amounts of copper(II) [55], which lead to a catalytic mechanism quite similar to Reactions 2-4 with the $\mathrm{C}^{-} \mathrm{C}^{-}$couple being $\mathrm{Cu}^{\mathrm{II}} / \mathrm{Cu}^{\mathrm{I}}$.

While the aqueous reduction potential for $\mathrm{S}_{2} \mathrm{O}_{3}{ }^{2-} / \mathrm{S}_{4} \mathrm{O}_{6}{ }^{2-}$ has been found to be $+0.08 \mathrm{~V}[56]$, the redox potential for the $\mathrm{S}_{2} \mathrm{O}_{3}{ }^{-} / \mathrm{S}_{2} \mathrm{O}_{3}{ }^{2-}$ couple is much less favorable $(-1.30 \mathrm{~V})$ [57]. The reaction is driven by the coupling of $\mathrm{S}_{2} \mathrm{O}_{3}{ }^{-}$with $\mathrm{S}_{2} \mathrm{O}_{3}{ }^{2-}$. The high potential for the initial

Inorganica Chimica Acta, Vol. 328, No. 1 (2002): pg. 13-22. DOI. This article is (C) Elsevier and permission has been granted for this version to appear in e-Publications@Marquette. Elsevier does not grant permission for this article to be further copied/distributed or hosted elsewhere without the express permission from Elsevier. 
oneelectron step is compensated for by the low kinetic barrier for the self-exchange reaction [57]. The fast electron exchange rate favors the involvement of a catalyst, via the mechanism described in Reactions 2-4. While the catalytic mechanism is consistent with the kinetic data, the identity of the catalyst is less clear. Kalinichenko et al. [49] postulated that the S/S- couple, formed by the hydrolysis is thiosulfate, was the catalytic couple.

$$
\mathrm{Fe}\left(\mathrm{S}_{2} \mathrm{O}_{3}\right)^{+}+\mathrm{H}_{2} \mathrm{O} \rightarrow \mathrm{Fe}^{2+}+\mathrm{SO}_{4}^{2-}+2 \mathrm{H}^{+}+\mathrm{S}^{-}
$$

Because only a small amount of $\mathrm{S}^{-}$would be required, the ferrous product from this reaction would be too small to be observed. While this mechanism is plausible, it is probably too early to speculate on the identity of the catalytic species.

The intriguing aspect of the reduction of $\mathrm{Fe}(\mathrm{P})(\mathrm{Cl})$ with thiosulfate is the effect of sulfate ion on the reaction. At high concentrations of sulfate (above 3-4 mM), the reaction was pseudofirst order with good isosbestic points during the entire reaction time and was faster than in the absence of sulfate (Figure 6). An examination of the visible spectra during the reaction indicated than most of the ferric-porphyrin was complexed with sulfate, rather than thiosulfate. The results indicate that the identity of the axial ligand is not important, but that the rate determining step is the reaction between the thiosulfate in solution and the complexed ferric porphyrin. When the sulfate concentration was less than $3 \mathrm{~m} \underline{\mathrm{M}}$, the two-step reaction, observed in the absence of sulfate, was observed. Previous spectral studies with sulfate and ferric porphyrins in DMSO indicated that dissociation of the complex appears below this concentration.

No effect on the kinetics of the ferric porphyrin reduction was observed when chloride was replaced with perchlorate. This is consistent with the complete conversion of the complex to $\mathrm{Fe}(\mathrm{TPP})^{+}$in DMSO, whether one starts with the chloro or perchlorate complex. In addition, the results observed with ferric-OEP were quite similar to the ferric-TPP complex. The kinetics was consistent with a two-step mechanism, though the reduction rate was slightly smaller with the OEP-macrocycle.

Inorganica Chimica Acta, Vol. 328, No. 1 (2002): pg. 13-22. DOI. This article is (C) Elsevier and permission has been granted for this version to appear in e-Publications@Marquette. Elsevier does not grant permission for this article to be further copied/distributed or hosted elsewhere without the express permission from Elsevier. 
In contrast with the reduction of $\mathrm{Fe}(\mathrm{TPP})(\mathrm{Cl})$ in DMSO, the reduction in DMF is much more sluggish. The complete reduction of $0.10 \mathrm{mM}$ Fe(TPP)(Cl) with $0.70 \mathrm{mM}$ thiosulfate takes about $12 \mathrm{hr}$. Isosbestic points were observed during the reduction, and the only species observed were $\mathrm{Fe}^{\mathrm{III}}(\mathrm{TPP})\left(\mathrm{S}_{2} \mathrm{O}_{3}\right)^{-}$and $\mathrm{Fe}^{\mathrm{II}}(\mathrm{TPP})$. These results are consistent with previous studies of the autoreduction of ferric porphyrins, which are significantly faster in DMSO than in other solvents.

\section{Thiosulfate Oxidation Product Isolation}

Equimolar amounts of $\mathrm{Fe}(\mathrm{P})(\mathrm{Cl})$, where $\mathrm{P}=$ OEP or TPP, were reacted with thiosulfate in DMF and DMSO. The product, isolated following addition of toluene to precipitate ionic compounds, yielded an infrared spectrum that closely corresponded to authentic $\left(\mathrm{Ph}_{4} \mathrm{P}\right)_{2} \mathrm{~S}_{4} \mathrm{O}_{6}$. In particular, bands were observed (authentic $\left(\mathrm{Ph}_{4} \mathrm{P}\right)_{2} \mathrm{~S}_{4} \mathrm{O}_{6}$ in parenthesis) at 592 (594), 629 (629) and 1230 (1232) $\mathrm{cm}^{-1}$, which were not present in $\mathrm{Ph}_{4} \mathrm{PCl}$. The tetrathionate ion could also be detected, along with unreacted thiosulfate ion, by thin-layer chromatography [58]. The visible spectroscopy of tetrathionate in the presence of $\mathrm{Fe}(\mathrm{TPP})(\mathrm{Cl})$ was examined and there was no evidence for the coordination of this species with the ferric porphyrin at the concentrations used in this experiment.

\section{Conclusions}

The reduction of ferric porphyrins with thiosulfate is complex because of the high barrier for the formation of $\mathrm{S}_{2} \mathrm{O}_{3}{ }^{-}$. Coordination of the ferric porphyrin with sulfate does not impede the reaction, indicating that prior coordination is not necessary for the reaction, though six-coordinate intermediates cannot be excluded. This is consistent with Reaction 3 in that the rate limiting step is the reaction of the ferric porphyrin (sulfate or thiosulfate coordinated) with the catalyst. The reaction of $\mathrm{S}_{2} \mathrm{O}_{3}{ }^{-}\left(\mathrm{S}_{4} \mathrm{O}_{6}{ }^{3-}\right)$ with the ferric porphyrin is not rate limiting. The change in the reaction to pseudo-first order in the present of sulfate may not necessarily indicate a change in mechanism, but may mean changes in the relative rate constants or concentration of the catalyst.

Inorganica Chimica Acta, Vol. 328, No. 1 (2002): pg. 13-22. DOI. This article is (C) Elsevier and permission has been granted for this version to appear in e-Publications@Marquette. Elsevier does not grant permission for this article to be further copied/distributed or hosted elsewhere without the express permission from Elsevier. 
The difference in the reactivity of ferric porphyrins with thiosulfate between DMF and DMSO is quite intriguing. The difference between these two solvents is generally not large, though DMSO does coordinate more strongly. The spectroscopic and voltammetric evidence is quite strong that thiosulfate coordinates well with ferric porphyrins in either solution. The cyclic voltammetry, in particular, shows that there is little dissociation of the complex, even with a small excess of thiosulfate. The similarity of the visible spectra between $\mathrm{Fe}(\mathrm{TPP})\left(\mathrm{SO}_{4}\right)^{-}$and $\mathrm{Fe}(\mathrm{TPP})\left(\mathrm{S}_{2} \mathrm{O}_{3}\right)^{-}$in DMSO could indicate that the coordination changed from a Fe-S to an Fe-O bonded complex, perhaps driven by axial coordination by DMSO. The EPR results were also indicative of a difference in iron coordination in these two solvents. In DMSO, the high spin complex does not completely disappear in the EPR spectrum even with an excess of thiosulfate, while only a low-spin complex was observed in DMF. The residual highspin ferric porphyrin at $77 \mathrm{~K}$ is probably due to an equilibrium concentration of an Fe-O complex. The formation constants for the displacement of chloride by thiosulfate ( $\mathrm{KTS}, \mathrm{Cl}$ ) were nearly the same in DMF and DMSO, based on the voltammetric data. As a result, the EPR differences cannot be due to the ability of ferric porphyrins to form the thiosulfate complex in the two solvents.

In addition, the reduction of ferric porphyrins with thiosulfate is also qualitatively different from the reduction by nitrite. In the latter case, the Fe-nitrite complex is the species that is reduced, and the rate of the reaction does not depend upon the concentration of free (uncoordinated) nitrite [59]. In the case of nitrite, though, the reduction of the ion must be accompanied by an acid/base or oxygen transfer reaction to form NO. The reduction of ferric porphyrins by nitrite has characteristics of an inner-sphere reaction, while the ferric porphyrin thiosulfate reaction appears to be outer-sphere in that coordination by thiosulfate is not the rate-limiting step in the oxidation process. This was indicated by the fact that the oxidation of thiosulfate was actually accelerated by the addition of sulfate, and that the rate of oxidation was controlled by the concentration of free, not-coordinated thiosulfate. It is not clear at this time as to why the mechanism of the auto-reduction of ferric porphyrins changes in the presence of sulfate, but these results confirm the complexity of the reaction of thiosulfate with ferric ion, as has been observed in the literature.

Inorganica Chimica Acta, Vol. 328, No. 1 (2002): pg. 13-22. DOI. This article is (C) Elsevier and permission has been granted for this version to appear in e-Publications@Marquette. Elsevier does not grant permission for this article to be further copied/distributed or hosted elsewhere without the express permission from Elsevier. 
NOT THE PUBLISHED VERSION; this is the author's final, peer-reviewed manuscript. The published version may be accessed by following the link in the citation at the bottom of the page.

Acknowledgments: The authors would like to thank William Antholine of the Medical College of Wisconsin for obtaining the EPR spectra, and Scott Reid for helpful discussions on chemical kinetics.

\section{Reference List}

[1] Peck, H. D., Jr. and LeGall, J. (Ed.), Inorganic Microbial Sulfur Metabolism, Academic Press, New York, 1994.

[2] R. Meulenberg, J. T. Pronk, W. Hazeu, J. P. Vandijken, J. Frank, P. Bos, and J. G. Kuenen, J. Gen. Microbiol. 139 (1993) 2033.

[3] W.-P. Lu and D. P. Kelly, J. Gen. Microbiol. 130 (1984) 1683.

[4] J. B. Fernandes, D. Feng, A. Chang, A. Keyser, and M. D. Ryan, Inorg. Chem. 25 (1986) 2606.

[5] D. Feng and M. D. Ryan, Inorg. Chem. 26 (1987) 2480.

[6] I.-K. Choi, Y. Liu, D. Feng, K. J. Paeng, and M. D. Ryan, Inorg. Chem. 30 (1991) 1832.

[7] Y. M. Liu and M. D. Ryan, J. Electroanal. Chem. 368 (1994) 209.

[8] L. M. Epstein, D. K. Straub, and C. Maricondi, Inorg. Chem. 6 (1967) 1720.

[9] G. N. LaMar and J. Del Gaudio, Adv. Chem. Ser. 162 (1977) 207.

[10] J. Del Gaudio and G. N. LaMar, J. Am. Chem. Soc. 100 (1978) 1112.

[11] J. Del Gaudio and G. N. LaMar, J. Am. Chem. Soc. 98 (1976) 3014.

[12] S. Modi, V. P. Shedbalkar, and D. V. Behere, Inorg. Chim. Acta 173 (1990) 9.

[13] C. J. Swan and D. L. Trimm, Adv. Chem. Ser. 76 (1968) 182.

[14] C. K. Chang and D. Dolphin, Proc. Natl. Acad. Sci. USA 73 (1976) 3338.

[15] K.Nakamoto, Infrared and Raman Spectra of Inorganic and Coordination Compounds, Wiley, New York, 1978.

[16] Y. O. Kim, B. H. Song, and H. M. Goff, Inorg. Chem. 32 (1993) 1304.

[17] P. W. Crawford and M. D. Ryan, Inorg. Chim. Acta 179 (1991) 25.

[18] M. A. Phillippi, N. Baenziger, and H. M. Goff, Inorg. Chem. 20 (1981) 3904.

[19] W. R. Scheidt, Y. J. Lee, T. Bartzcak, and K. Hatano, Inorg. Chem. 23 (1984) 2552.

[20] M. S. Reynolds and R. H. Holm, Inorg. Chim. Acta 155 (1989) 113.

[21] R.G.Wilkins, The Study of Kinetics and Mechanism of Reactions of Transition Metal Complexes, Allyn and Bacon, Inc., Boston, 1974.

[22] A. McAuley, Coord. Chem. Rev. 5 (1970) 245.

[23] C. E. Ophardt, J. Chem. Ed. 64 (1987) 716.

[24] W. K. Wilmarth, D. M. Stanbury, J. E. Byrd, H. N. Po, and C.-P. Chua, Coord. Chem. Rev. 51 (1983) 155.

[25] S. M. Chen, J. Mol. Cat. A 138 (1999) 1.

Inorganica Chimica Acta, Vol. 328, No. 1 (2002): pg. 13-22. DOI. This article is (C) Elsevier and permission has been granted for this version to appear in e-Publications@Marquette. Elsevier does not grant permission for this article to be further copied/distributed or hosted elsewhere without the express permission from Elsevier 
[26] S. M. Chen, J. Electroanal. Chem. 432 (1997) 101.

[27] S. M. Chen, Inorg. Chim. Acta 244 (1996) 155.

[28] A. D. Adler, F. R. Longo, and V. Varadi, Inorg. Syn. 16 (1976) 213.

[29] R. Larsson, B. Falkesson, and R. Lykvist, Chem. Scr. 13 (1979) 178.

[30] A.J.Banister, L.F.Moore, and J.S.Padley in Inorganic Sulphur Chemistry, Nickless, G. (Ed.), Elsevier Publishing Company, Amsterdam, 1968, p. 137-198.

[31] K. Buijs, J. Inorg. Nucl. Chem. 24 (1962) 229.

[32] A. Martinsen and J. Songstad, Acta Chem. Scand. Ser. A A31 (1977) 645.

[33] C. A. Reed, J. K. Kouba, C. J. Grimes, and S. K. Cheung, Inorg. Chem. 17 (1978) 2666.

[34] J. T. Landrum, K. Hatano, W. R. Scheidt, and C. A. Reed, J. Am. Chem. Soc. 102 (1980) 6729.

[35] X. Q. Lin and K. M. Kadish, Anal. Chem. 57 (1985) 1498.

[36] R. A. Hasty and S. L. Sutter, Can. J. Chem. 47 (1969) 4537.

[37] D. Lexa, M. Momenteau, and J. Mispelter, Biochim. Biophys. Acta 338 (1974) 151.

[38] E. B. Fleischer, J. M. Palmer, T. S. Srivastava, and Chatterjee.A., J. Am. Chem. Soc. 93 (1971) 3162.

[39] C. A. Reed, T. Mashiko, S. P. Bentley, M. E. Kastner, W. R. Scheidt, K. Spartalian, and G. Lang, J. Am. Chem. Soc. 101 (1979) 2948.

[40] D. H. Dolphin, J. R. Sams, and T. B. Tsin, Inorg. Chem. 16 (1977) 711.

[41] H. Sugimoto, N. Ueda, and M. Mori, Bull. Chem. Soc. Jpn. 55 (1982) 3468.

[42] M. A. Phillippi and H. M. Goff, J. Chem. Soc. ,Chem. Commun. (1980) 455.

[43] S. C. Tang, S. Koch, G. C. Papaefthymiou, S. Foner, R. B. Frankel, J. A. Ibers, and R. H. Holm, J. Am. Chem. Soc. 98 (1976) 2414.

[44] H. Oshio, T. Ama, T. Watanabe, and K. Nakamoto, Inorg. Chim. Acta 96 (1985) 61.

[45] H. Aissaoui, S. Ghirlanda, C. Gmur, and W.-D. Woggon, J. Mol. Cat. A 113 (1996) 393.

[46] D. R. English, D. N. Hendrickson, K. S. Suslick, C. W. Eigenbrot, Jr., and W. R. Scheidt, J. Am. Chem. Soc. 106 (1984) 7258.

[47] S. E. Jones, G. S. Srivatsa, D. T. Sawyer, T. G. Traylor, and T. C. Mincey, Inorg. Chem. 22 (1983) 3903.

[48] R. Tauler, A. K. Smilde, J. M. Henshaw, L. W. Burgess, and B. R. Kowalski, Anal. Chem. 66 (1994) 3337.

[49] I. E. Kalinichenko, E. P. Rodina, and V. V. Trachevskii, Zhurnal Obshchei Khimii 67 (1997) 47.

[50] R. Sarala, S. B. Rabin, and D. M. Stanbury, Inorg. Chem. 30 (1991) 3999.

Inorganica Chimica Acta, Vol. 328, No. 1 (2002): pg. 13-22. DOI. This article is (C) Elsevier and permission has been granted for this version to appear in e-Publications@Marquette. Elsevier does not grant permission for this article to be further copied/distributed or hosted elsewhere without the express permission from Elsevier. 
NOT THE PUBLISHED VERSION; this is the author's final, peer-reviewed manuscript. The published version may be accessed by following the link in the citation at the bottom of the page.

[51] K. Shin, S. K. Kramer, and H. M. Goff, Inorg. Chem. 26 (1987) 4103.

[52] G. S. Srivatsa and D. T. Sawyer, Inorg. Chem. 24 (1985) 1732.

[53] T. Otsuka, T. Ohya, and M. Sato, Inorg. Chem. 24 (1985) 776.

[54] F. M. Page, Trans. Faraday Soc. 56 (1960) 398.

[55] M. Kimura and M. Ishibashi, Inorg. Chim. Acta 129 (1987) 69.

[56] W.H.Latimer, The Oxidation States of the Elements and Their Potentials in Aqueous Solutions, Prentice Hall, Englewood Cliffs, NJ, 1952.

[57] R. Sarala and D. M. Stanbury, Inorg. Chem. 31 (1992) 2771.

[58] A. Westley and J. Westley, Anal. Biochem. 142 (1984) 163.

[59] J.B.Fernandes, Spectroscopic and electrochemical study of iron porphyrins and chlorins in the presence of nitrite in nonaqueous solvents, Ph.D. Thesis, Marquette University, 1988.

Table 1

Visible spectra of ferric porphyrins with anioas

\begin{tabular}{|c|c|c|c|}
\hline Compound & Solvent & 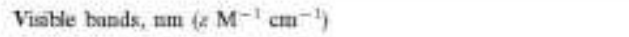 & Reference \\
\hline \multirow[t]{2}{*}{ FerTPPX(x) } & DMF & $380(50), 416,(95), 508(12), 572(4), 690$ & [3?] \\
\hline & $\mathrm{CH}_{2} \mathrm{O}_{2}$ & $350=59), 417(110), 511(13.4), 5779(3.3), 658,690$ (3.2) & {$[38]$} \\
\hline $\mathrm{Fa}\left(\mathrm{TPP} y\left(\mathrm{~S}_{2} \mathrm{O}_{3}\right)^{-}\right.$ & DMF & $402(95), 508(15,6), 568,6068$ & this work \\
\hline \multirow[t]{2}{*}{$\mathrm{Fe}(\mathrm{TPP})\left(\mathrm{SO}_{4}\right)^{-}$} & DMF & $425(187), 567(15.8), 609(7.8), 66013$ & [17] \\
\hline & DMSO & $420(272), 5506,566(15,3), 619(80)$ & [17] \\
\hline \multirow[t]{3}{*}[\mathrm{ForTPP}]{$\mathrm{SO}_{4}$} & DMF & $400(93), 501(8.2), 530(10.6), 693(4.3)$ & [17] \\
\hline & DMSO & $416,490,526,571 s, 617,678$ & this work \\
\hline & $\mathrm{CH}_{2} \mathrm{Cl}_{2}$ & $347(43), 372(51), 408(113), 508(110), 596(3.5), 680(2.9)$ & {$[18]$} \\
\hline $\mathrm{Fe}(\mathrm{TPP})\left(\mathrm{COO}_{4}\right)$ & tolowe & $408(99.5), 513(9.5), 570(2.4), 608(1.4), 650(1.2), 675(13)$ & [39] \\
\hline \multirow[t]{3}{*}{$\mathrm{Fe}(O E P)(\mathrm{CT})$} & DMSO & $390(116.7), 454(7.3), 495(88), 530 \mathrm{k}, 572(4.4), 616(59)$ & this work \\
\hline & DMF & $380(88.4), .94(9.1), 532(9.1), 630(5.2)$ & this work \\
\hline & $\mathrm{CH}_{2} \mathrm{Cl}_{2}$ & $381(35.1), 461(5.75), 508(7.4), 536(7.76), 584(2.14), 640(3.50)$ & [41] \\
\hline $\mathrm{FaOEP}\left(\mathrm{ClO}_{2}\right)$ & $\mathrm{CH}_{2} \mathrm{Cl}_{2}$ & $380(113), 500-(9.2), 633(3.2)$ & {$[40]$} \\
\hline \multirow[t]{3}{*}{$\mathrm{FeOEP}\left(\mathrm{S}_{2} \mathrm{O}_{2}\right)^{-}$} & DMSO & $374,502,5403,5895,629$ & His work \\
\hline & DMF & $374,503,532 s, 585 s, 624 s$ & this work \\
\hline & edtyleae chloride & $397(117), 504(9.2), 533,(9.4), 5839,634(4.6)$ & this work \\
\hline$\left[\mathrm{Fo} / \mathrm{OEP}_{2} \mathrm{~L}_{2}\left(\mathrm{SO}_{4}\right)\right.$ & $\mathrm{CHCl}_{3}$ & $387(65), 506(6.2), 530(5.9), 627(2.6)$ & this work \\
\hline $\mathrm{FaOEPY}\left(\mathrm{SO}_{a}\right)^{-}$ & $\mathrm{CHC}_{3}$ & $391(79), 473(11), 582(4.1)$ & this work \\
\hline $\mathrm{Fe}(\mathrm{OEP})\left(\mathrm{HSO}_{2}\right)$ & $\mathrm{CHCl}_{3}$ & $382(77.9), 504(7.8), 5304,636(1.0)$ & [17] \\
\hline
\end{tabular}

Table 2

Proton NMR spectrum of ferric porplayrins

\begin{tabular}{|c|c|c|c|c|c|}
\hline \multirow[t]{2}{*}{ Compound } & \multirow[t]{2}{*}{ Solvent } & \multicolumn{3}{|l|}{$\delta$ (ppen) } & \multirow[t]{2}{*}{ Reference } \\
\hline & & Pyrrole & Phenyl & Methylene & \\
\hline \multirow[t]{2}{*}{ Fo'TPPXCI) } & $\mathrm{DMF}_{-} \mathrm{d}_{2}$ & 82.5 & $12.2,13.2$ & & This work \\
\hline & $\mathrm{DMSO}_{\varepsilon^{4}}$ & 86.3 & $9.9,11.7,12.7$ & & This work \\
\hline \multirow{2}{*}{ FeATPPX $\left.X S_{2} \mathrm{O}_{3}\right)^{-1}$} & DMF-d & 77.0 & $11.4,12.8$ & & This work \\
\hline & DMSO-d & 766 & 11.4 .12 .9 & & This work \\
\hline Fo'TPPXSOHA & $\mathrm{DMF}-\mathrm{d}_{7}$ & 80.9 & $13.0,11,9,10.3$ & & This work \\
\hline \multirow{2}{*}{$\mathrm{Fe}(\mathrm{TPP})_{2}\left(\mathrm{SO}_{4}\right)$} & DMF-d & 67.0 & $13.7,10.2,10.1,8.9$ & & This work \\
\hline & $\mathrm{CDCh}_{3}$ & 69.6 & $12.3,10.5,6.3$ & & [18] \\
\hline \multirow[t]{2}{*}{ Fed $\left.\left.O E^{2}\right)(C]\right)$} & DMF-d & & & $409,43.7$ & This wotk \\
\hline & $\mathrm{CDC}_{3}$ & & & $39.6,43.1$ & [18] \\
\hline $\mathrm{Fe}(\mathrm{OEP})\left(\mathrm{S}_{2} \mathrm{O}_{3}\right)$ & DMF- $d_{7}$ & & & $3 x, 3,37,3$ & This work \\
\hline $\mathrm{Fe}(\mathrm{OEP})\left(\mathrm{SO}_{4}\right)^{-}$ & $\mathrm{CDCl}_{3}$ & & & $38.8,49.8$ & [17) \\
\hline [FelOEP] $\mathrm{SO}_{4}$ & $\mathrm{CDCl}_{3}$ & & & 37.9 & [18.42] \\
\hline $\left.\mathrm{Fe}(\mathrm{OEP}) \mathrm{HSO}_{4}\right\}$ & $\mathrm{CDCB}_{3}$ & & & $39.7,49.8$ & [17] \\
\hline
\end{tabular}

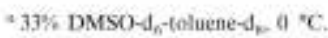

Inorganica Chimica Acta, Vol. 328, No. 1 (2002): pg. 13-22. DOI. This article is C Elsevier and permission has been granted for this version to appear in e-Publications@Marquette. Elsevier does not grant permission for this article to be further copied/distributed or hosted elsewhere without the express permission from Elsevier 
NOT THE PUBLISHED VERSION; this is the author's final, peer-reviewed manuscript. The published version may be accessed by following the link in the citation at the bottom of the page.

Table 3

Cyclic voltammetry of FefTPPyCly in the presence of thiosulfate ion in DMF *

\begin{tabular}{|c|c|c|c|c|c|c|}
\hline \multirow[t]{2}{*}[\mathrm{S};\mathrm{O}_{3}{}^{-}]{$(\mathrm{mM})$} & \multicolumn{2}{|c|}{ Wave ta } & \multicolumn{2}{|c|}{ Wave $1 \mathrm{~b}$} & \multicolumn{2}{|c|}{ Wave II } \\
\hline & $E_{3 / 2} \mathrm{~h}$ & $i_{1} \in(\mu \mathrm{A})$ & $E_{5 x}{ }^{b}$ & $i_{p}<(1-\hat{A})$ & $E_{1 ; 2}=$ & $f_{T<}(\mu A)$ \\
\hline 0 & -0.60 & $\pi$ & & & -1.48 & 84 \\
\hline 0.13 & -0.60 & 62 & -1.01 & th. 5 & -1.48 & 103 \\
\hline 0.25 & -0.61 & 44 & -1.06 & 16 & -1.48 & 98 \\
\hline 0.50 & -0.61 & 19 & -1.08 & 46 & $-1.4 ?$ & 95 \\
\hline 0.75 & & & -1.17 & 54 & -1.48 & 90 \\
\hline 1.0 & & & -1.08 & 72 & -1.48 & 108 \\
\hline 1.5 & & & -1.18 & 56 & -1.49 & 83 \\
\hline 2.5 & & & -1.21 & 59 & $-1.4 ?$ & 78 \\
\hline
\end{tabular}

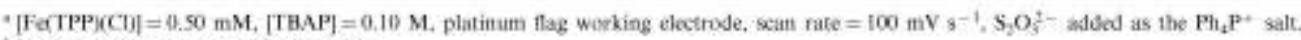
V v. $0.10 \mathrm{M} \mathrm{Ag} / \mathrm{AgNO}$, in $\mathrm{CH}_{3} \mathrm{CN}$.

Inorganica Chimica Acta, Vol. 328, No. 1 (2002): pg. 13-22. DOI. This article is (C) Elsevier and permission has been granted for this version to appear in e-Publications@Marquette. Elsevier does not grant permission for this article to be further copied/distributed or hosted elsewhere without the express permission from Elsevier. 
NOT THE PUBLISHED VERSION; this is the author's final, peer-reviewed manuscript. The published version may be accessed by following the link in the citation at the bottom of the page.

\section{Figure Captions}

Figure 1. Solid line. Visible spectrum of $0.10 \mathrm{mM} F(T P P)(\mathrm{Cl})$ with $0.71 \mathrm{mM}\left(\mathrm{Ph}_{4} \mathrm{P}\right)_{2}\left(\mathrm{~S}_{2} \mathrm{O}_{3}\right)$ in DMF. Dashed line. Visible spectrum obtained by the oxidation of $0.50 \mathrm{mM} \mathrm{Fe}{ }^{\mathrm{II}}(\mathrm{TPP})$ at $-0.30 \mathrm{~V}$ vs $\mathrm{Ag} / \mathrm{AgNO}_{3}$ in $\mathrm{DMF}$ in the presence of $3.8 \mathrm{mM}\left(\mathrm{Ph}_{4} \mathrm{P}\right)_{2}\left(\mathrm{~S}_{2} \mathrm{O}_{3}\right)$.

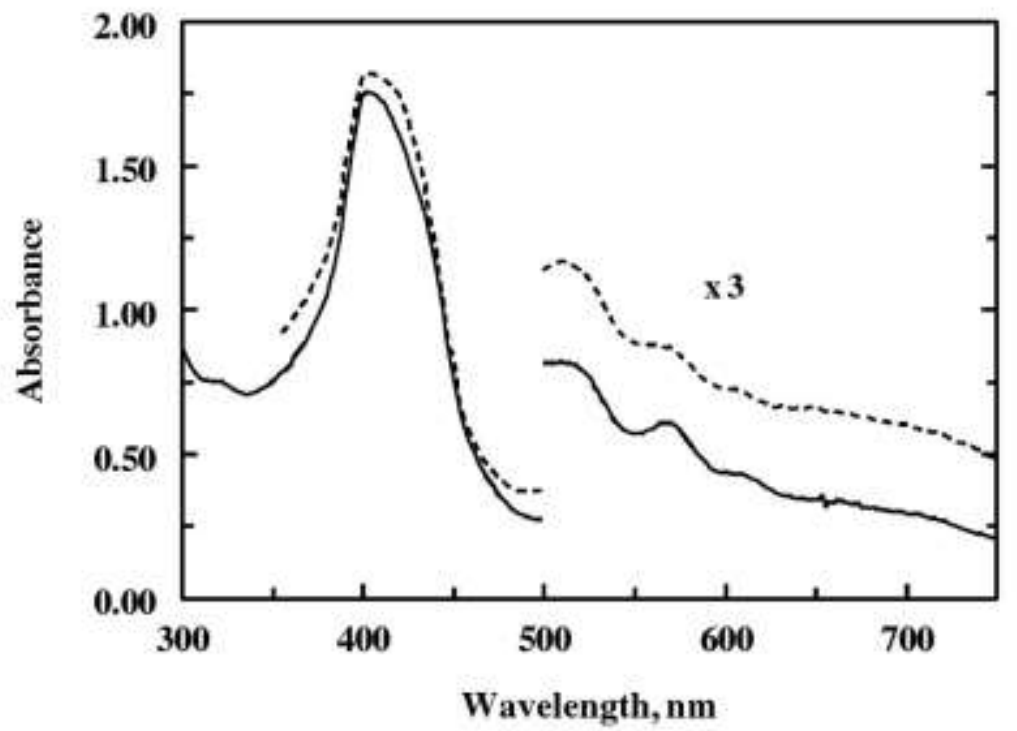

Inorganica Chimica Acta, Vol. 328, No. 1 (2002): pg. 13-22. DOI. This article is C Elsevier and permission has been granted for this version to appear in e-Publications@Marquette. Elsevier does not grant permission for this article to be further copied/distributed or hosted elsewhere without the express permission from Elsevier. 
NOT THE PUBLISHED VERSION; this is the author's final, peer-reviewed manuscript. The published version may be accessed by following the link in the citation at the bottom of the page.

Figure 2. A. Cyclic voltammetry of $0.50 \mathrm{mM}[\mathrm{Fe}(\mathrm{TPP})]_{2}\left(\mathrm{SO}_{4}\right)$ in DMF with $10 \mathrm{mM}(\mathrm{PNP})_{2}\left(\mathrm{SO}_{4}\right)$. Scan rate: $100 \mathrm{mV} / \mathrm{s}$. B. Cyclic voltammetry $0.50 \mathrm{mM} \mathrm{Fe}(\mathrm{TPP})(\mathrm{Cl})$ in the presence of $\mathrm{mM}\left(\mathrm{Ph}_{4} \mathrm{P}\right)_{2}\left(\mathrm{~S}_{2} \mathrm{O}_{3}\right)$ in DMF. Scan rates: 50, 100, $200 \mathrm{mV} / \mathrm{s}$. Working and auxiliary electrodes were platinum. Supporting electrolyte: $0.10 \underline{M}$ TBAP.

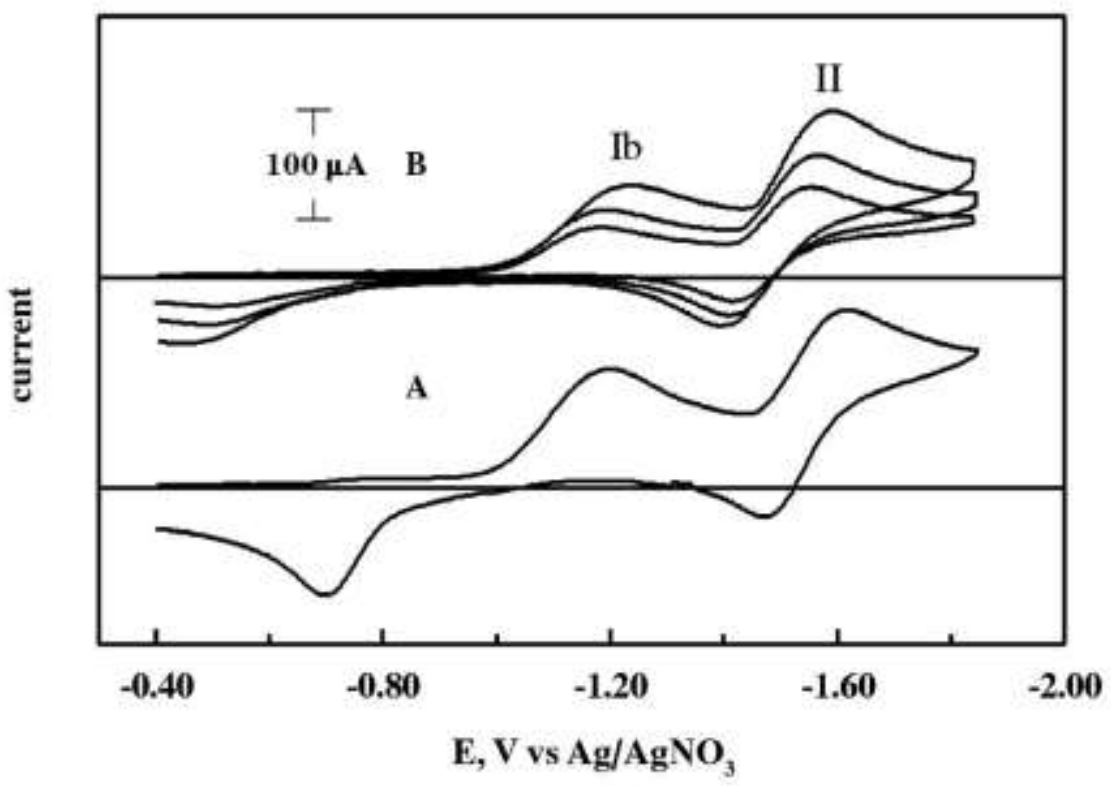

Inorganica Chimica Acta, Vol. 328, No. 1 (2002): pg. 13-22. DOI. This article is (C Elsevier and permission has been granted for this version to appear in e-Publications@Marquette. Elsevier does not grant permission for this article to be further copied/distributed or hosted elsewhere without the express permission from Elsevier. 
NOT THE PUBLISHED VERSION; this is the author's final, peer-reviewed manuscript. The published version may be accessed by following the link in the citation at the bottom of the page.

Figure 3. Visible spectra obtained during the reduction of $\mathrm{Fe}(\mathrm{TPP})(\mathrm{Cl})$ by thiosulfate in DMSO. $[\mathrm{Fe}(\mathrm{TPP})(\mathrm{Cl})]=0.0355 \mathrm{mM} ;\left[\mathrm{S}_{2} \mathrm{O}_{3}{ }^{2-}\right]=0.88$ $\mathrm{mM}$.

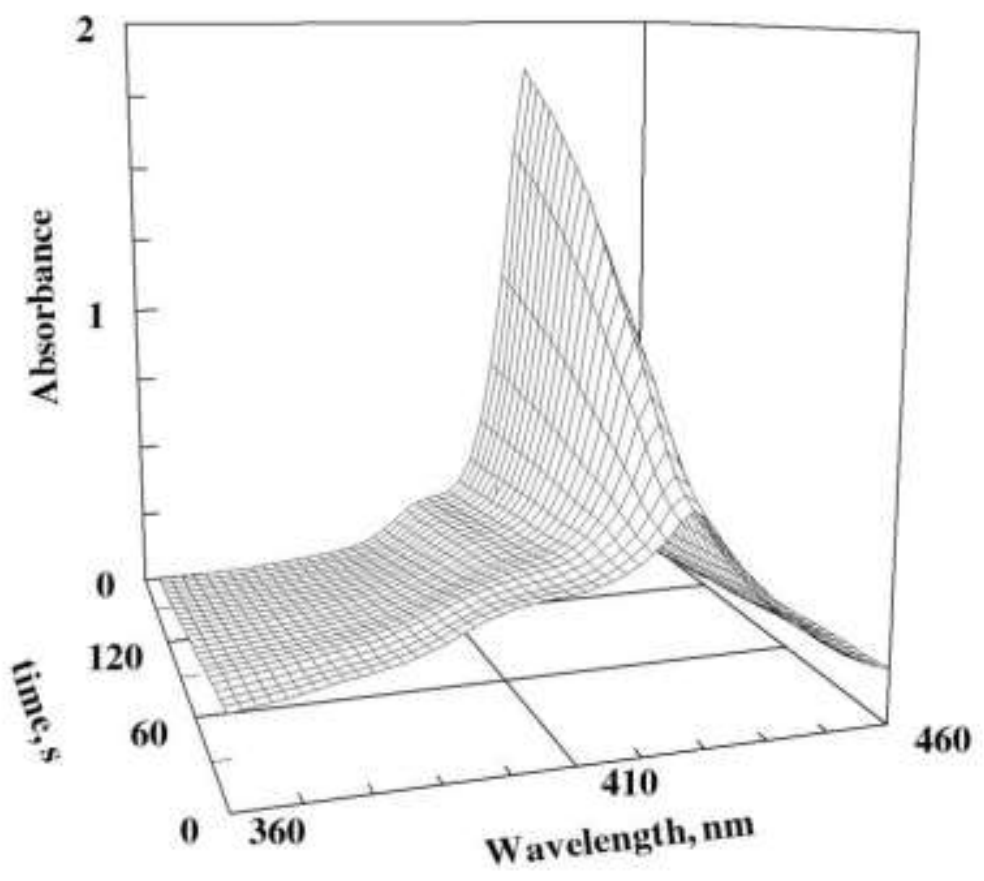


NOT THE PUBLISHED VERSION; this is the author's final, peer-reviewed manuscript. The published version may be accessed by following the link in the citation at the bottom of the page.

Figure 4. Window evolving factor analysis of the visible spectra for the reduction of $\mathrm{Fe}(\mathrm{TPP})(\mathrm{Cl})$ in DMSO by thiosulfate. $[\mathrm{Fe}(\mathrm{TPP})(\mathrm{Cl})]=$ $0.0355 \mathrm{mM} .\left[\mathrm{S}_{2} \mathrm{O}_{3}{ }^{2-}\right]=1.4 \mathrm{~m} \underline{\mathrm{M}}$.

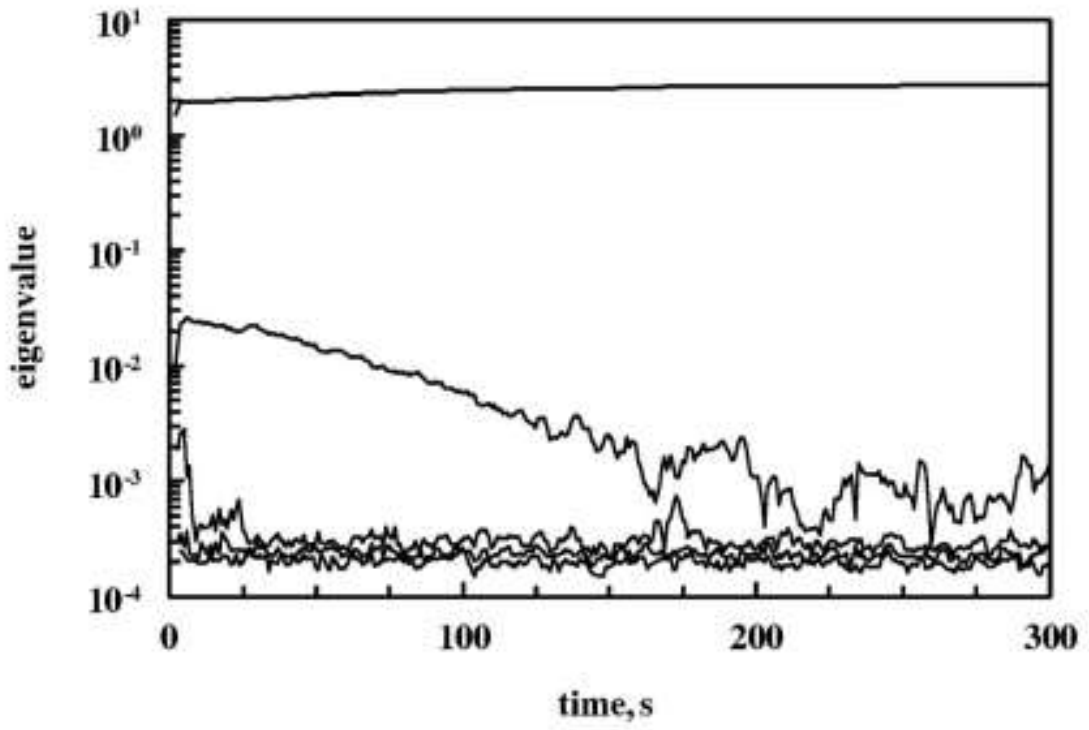


NOT THE PUBLISHED VERSION; this is the author's final, peer-reviewed manuscript. The published version may be accessed by following the link in the citation at the bottom of the page.

Figure 5. Variation in the concentration of the ferrous and ferric porphyrin as a function of time as calculated by the multivariant curve resolution method. $\left[\mathrm{Fe}(\mathrm{TPP})^{+}\right]=0.0355 \mathrm{mM} ;\left[\mathrm{S}_{2} \mathrm{O}_{3}{ }^{2-}\right]=0.88 \mathrm{mM}$. Solvent $=$ DMSO.

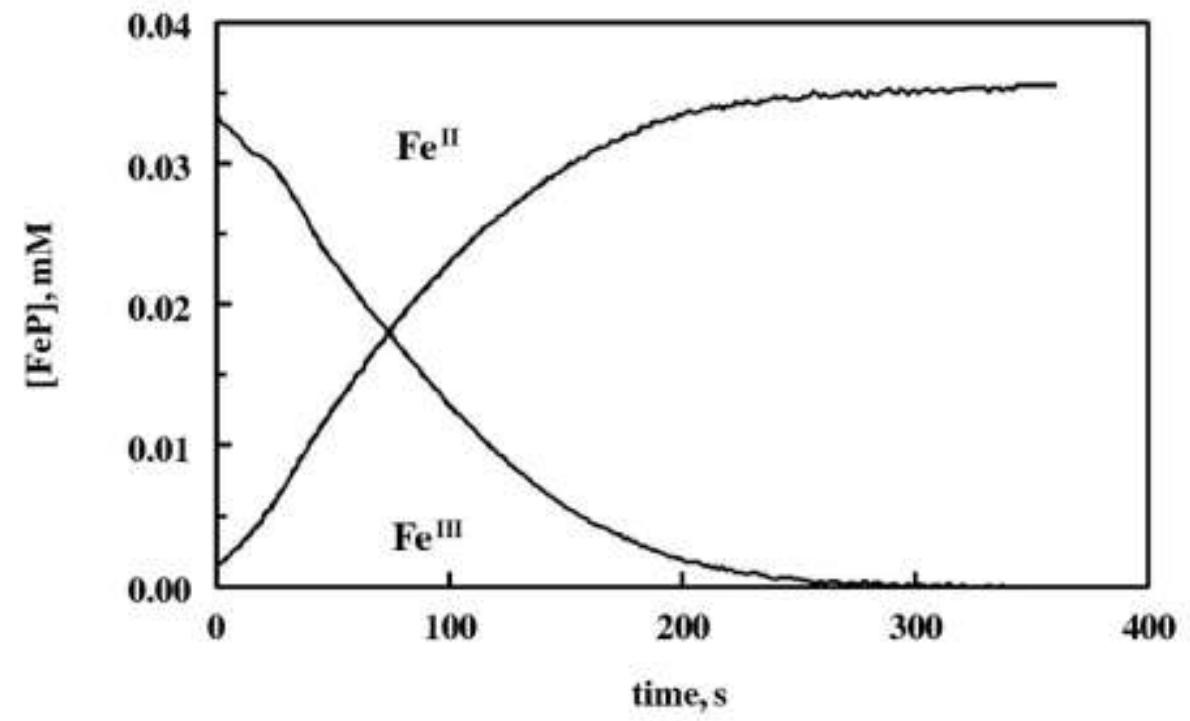

Inorganica Chimica Acta, Vol. 328, No. 1 (2002): pg. 13-22. DOI. This article is (C Elsevier and permission has been granted for this version to appear in e-Publications@Marquette. Elsevier does not grant permission for this article to be further copied/distributed or hosted elsewhere without the express permission from Elsevier. 
NOT THE PUBLISHED VERSION; this is the author's final, peer-reviewed manuscript. The published version may be accessed by following the link in the citation at the bottom of the page.

Figure 6. Variation in the concentration of the ferric porphyrin species as a function of time. $\left[\mathrm{Fe}(\mathrm{TPP})^{+}\right]=0.0355 \mathrm{mM}$. $\left[\mathrm{S}_{2} \mathrm{O}_{3}{ }^{2-}\right]:(\mathbf{\Delta}) 0.11$ $\mathrm{mM}$; (ㅁ) $0.59 \mathrm{mM}$; (o) $0.88 \mathrm{mM} ;(\nabla) 1.4 \mathrm{mM} ;(\nabla) 1.8 \mathrm{mM}$. k3k4 [C] $=0.88 \mathrm{M}-1 \mathrm{~s}-2, \mathrm{k} 3 / \mathrm{k} 4=32 ;(\bullet) 9.8 \mathrm{mM}$ sulfate, $0.38 \mathrm{mM}$ thiosulfate, $0.048 \mathrm{mM} \mathrm{Fe}(\mathrm{TPP})^{+}$. Line is theoretical line for a pseudo-first reaction with $\mathrm{k}=0.026 \mathrm{~s}^{-1}$

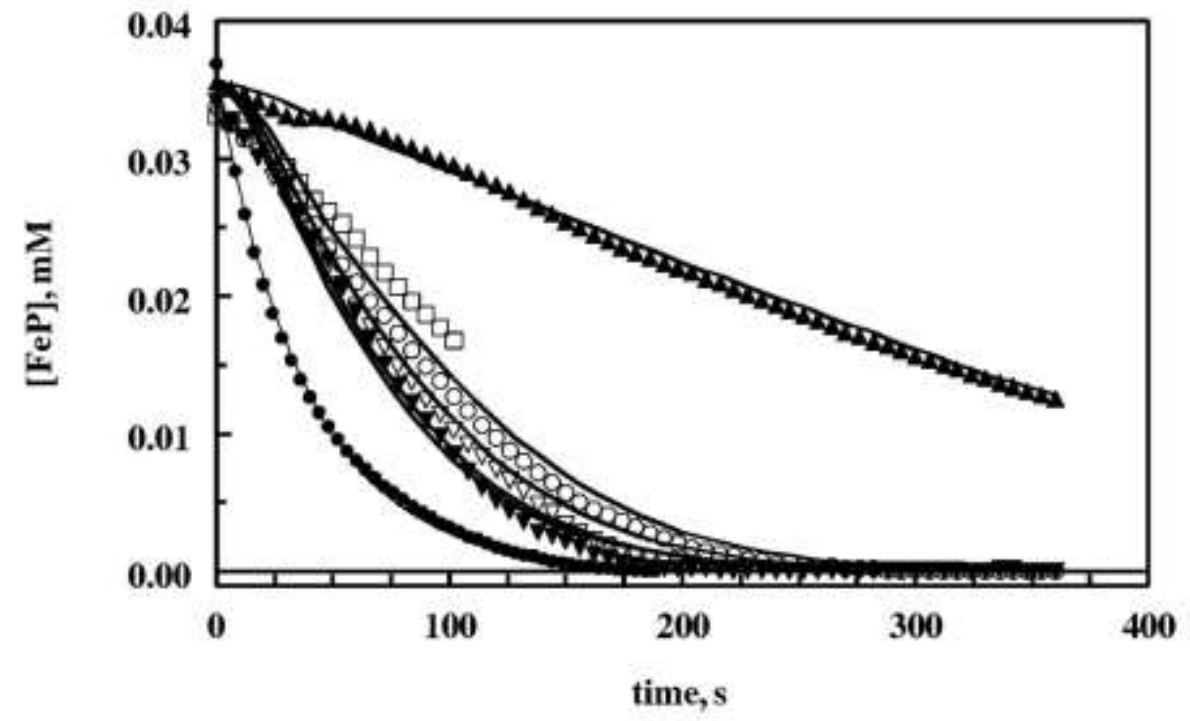

Inorganica Chimica Acta, Vol. 328, No. 1 (2002): pg. 13-22. DOI. This article is (C) Elsevier and permission has been granted for this version to appear in e-Publications@Marquette. Elsevier does not grant permission for this article to be further copied/distributed or hosted elsewhere without the express permission from Elsevier. 
NOT THE PUBLISHED VERSION; this is the author's final, peer-reviewed manuscript. The published version may be accessed by following the link in the citation at the bottom of the page.

Figure 7. Variation in the concentration of the ferric porphyrin species as a function of time. $\left[\mathrm{S}_{2} \mathrm{O}_{3}{ }^{2-}\right]=0.44 \mathrm{mM}$. $\left[\mathrm{Fe}^{\mathrm{III}}(\mathrm{TPP})^{+}\right]:(\mathbf{\Delta}) 0.00995$ $\mathrm{m} \underline{\mathrm{M}} ;(\Delta) 0.0207 \mathrm{~m} \underline{\mathrm{M}} ;(\boldsymbol{\nabla}) 0.041 \mathrm{~m} \underline{\mathrm{M}} ;(\diamond) 0.071 \mathrm{mM} ;(\bullet) 0.101 \mathrm{~m} \underline{\mathrm{M}}$.

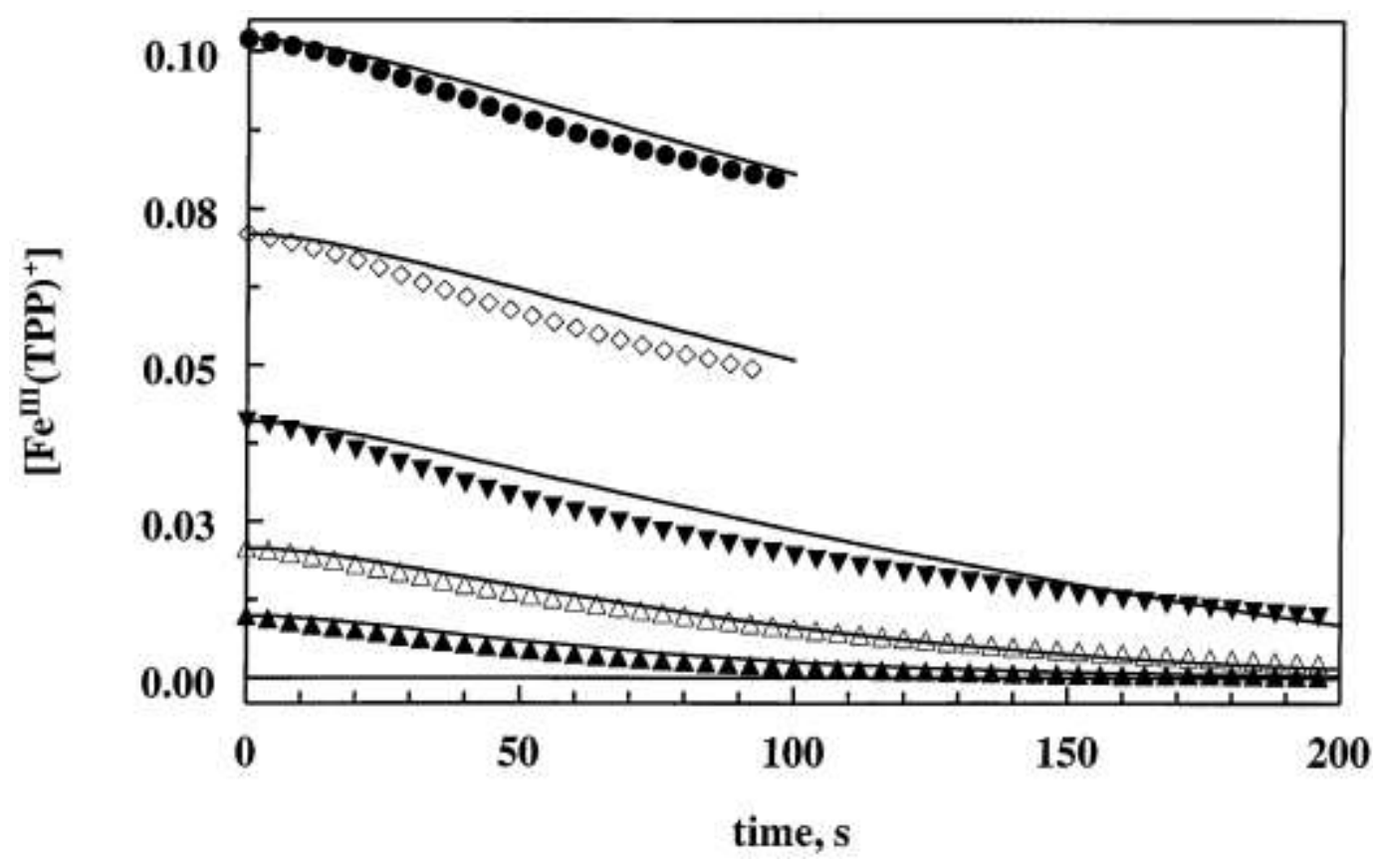

Inorganica Chimica Acta, Vol. 328, No. 1 (2002): pg. 13-22. DOI. This article is (C Elsevier and permission has been granted for this version to appear in e-Publications@Marquette. Elsevier does not grant permission for this article to be further copied/distributed or hosted elsewhere without the express permission from Elsevier. 